\title{
Salutogenesis and the Sense of Coherence During the Adolescent Years
}

\author{
Orna Braun-Lewensohn, Orly Idan, Bengt Lindström, \\ and Malka Margalit
}

\section{The Developmental Stage of Adolescence}

Adolescence is a period of growth and development between childhood and adulthood. This developmental period involves new demands on the individual. A major task of this period is moving toward independence from dependency on the family; therefore, peers become a crucial socialization circle for the adolescent (Romeo, 2013; Spear, 2013). During this period, several physiological and cognitive changes occur as young people confront developmental tasks and challenges. During the last decade, there has been a marked increase in neurobiological research on cognitive, emotional, and behavioral changes, and development during adolescence. These studies have found that cognitively, adolescents, as well as adults, can suppress responses when no emotional information is provided (Tottenham et al., 2011). However, it is the avoidance of social cues during challenging situations in which adolescents have a difficulty to make a proper and rational response (Casey \& Caudle, 2013). Thus, it seems that tension between regulation of behavior and sensitivity to positive environmental cues makes the response of the individual during the period of adolescence more complex (Somerville et al., 2011).

The adolescent, at the very best, can only have gained a tentative strong SOC, which may be useful for a short-range prediction about coping with stressors and health status (Antonovsky, 1987, p. 107).

O. Braun-Lewensohn $(\bowtie)$

Conflict Management \& Resolution Program, Ben-Gurion

University of the Negev, Beer Sheva, Israel

e-mail: ornabl@bgu.ac.il

O. Idan

School of Psychology, Interdisciplinary Center (IDC),

Herzliya, Israel

B. Lindström

NTNU Center for Health Promotion Research, Norwegian

University of Science and Technology, Trondheim, Norway

e-mail: bengtblind@hotmail.com

M. Margalit

Tel Aviv University, Peres Academic Center, Rehovot, Israel
In line with the positive youth development perspectives (Damon, 2004), there is a growing recognition of the individuals who are eager to explore the world, to acquire competence, and to struggle with challenges and difficulties. This approach focuses on productive activities rather than on trying to cure and treat maladaptive tendencies. The agenda is to maximize the potential of the individual and to reduce the potential of hazardous, destructive, and antisocial behaviors (Lerner \& Benson, 2003). The period of adolescence is a particularly important developmental stage since social, emotional, and cognitive processes are involved in attempts to navigate increasingly complex relationships (Blakemore \& Mills, 2014). Indeed, it is during these years that abstract thinking and cognitive processing develop along with enhanced moral reasoning and judgment. These positive processes enable the adolescent to explore the world, gain competences, and contribute to the world surrounding him/her (Damon, 2004). As children age, their coping repertoire expands and shifts from primarily external, behavior-oriented to more internal, cognitively based strategies (Aldwin et al., 1994).

The advanced forms of reflection, such as the ability to consider things in hypothetical and abstract terms, and the ability to monitor one's cognitive activity during the process of thinking, enable adolescents to see from the perspective of other persons, to plan, to anticipate the future consequences of an action, and to offer alternative explanations of events. Cognitive mastery is, therefore, an important contribution to young people's ability to manage or regulate their feelings and to control their emotions and/or avoid being overwhelmed by them (Garnefski et al., 2001). These abilities also have the potential to influence the emotional-motivational and behavioral components of sense of coherence (SOC). It is during these years, as young people move from one experience of using specific coping resources to another, that different resources can be reviewed and crystalized.

In the following section, we present adjustments to the SOC questionnaire and discuss a variety of ways that researchers have approached the study of salutogenesis and adolescence. 


\section{Studies of SOC During Adolescence}

Our literature search used Ebsco, PsycInfo, PubMed, SocioFile, and GoogleScholar, and we searched the sites of the publishers Sage, Springer, and Wiley. We looked at the last decade from 2014 to 2019 and included the search words: adolecs*, youth, sense of coherence, and salutogenesis. We came up with more than 30 articles and research from 16 countries in Europe, the Middle East, Australia, and the United States. Table 16.1 summarizes these studies.

The following themes emerged from the identified studies.

Table 16.1 Studies of SOC during adolescence

\begin{tabular}{|c|c|c|c|c|c|}
\hline Author & Year & Place & Population & Variables & Results \\
\hline 1. Abu-Kaf et al. & 2017 & Israel & $\begin{array}{l}\text { Jewish and Bedouin } \\
\text { adolescents, aged } \\
14-18 \text {, during a period } \\
\text { of escalated political } \\
\text { violence }\end{array}$ & $\begin{array}{l}\text { SOC, hope, anxiety, } \\
\text { anger }\end{array}$ & $\begin{array}{l}\text { Bedouin Arab adolescents reported lower } \\
\text { levels of SOC and higher levels of hope } \\
\text { and anger, compared to Jewish } \\
\text { adolescents. SOC contributed } \\
\text { significantly to the reduction of state } \\
\text { anxiety only among the Jewish } \\
\text { adolescents }\end{array}$ \\
\hline $\begin{array}{l}\text { 2. Abu-Kaf \& } \\
\text { Braun-Lewensohn }\end{array}$ & 2019 & Israel & $\begin{array}{l}\text { Bedouin Arab } \\
\text { adolescents, } \\
\text { 14-18 years old, } \\
\text { during three periods of } \\
\text { escalated political } \\
\text { violence }\end{array}$ & $\begin{array}{l}\text { SOC, hope, anxiety, } \\
\text { anger, psychological } \\
\text { distress }\end{array}$ & $\begin{array}{l}\text { Over time, SOC was found to be a } \\
\text { significant predictor of those stress } \\
\text { reactions, whereas the association } \\
\text { between hope components and stress } \\
\text { reactions weakened over time }\end{array}$ \\
\hline 3. Al-Said et al. & 2018 & Israel & $\begin{array}{l}\text { Bedouin adolescents, } \\
13-18 \text { years old, from } \\
\text { recognized and } \\
\text { unrecognized villages; } \\
\text { some had experienced } \\
\text { home demolitions }\end{array}$ & $\begin{array}{l}\text { SOC, emotional } \\
\text { reactions }\end{array}$ & $\begin{array}{l}\text { Stress reactions were strongest among } \\
\text { adolescents from unrecognized villages } \\
\text { with demolitions. Personal SOC was } \\
\text { related to fewer emotional reactions } \\
\text { among the adolescents from recognized } \\
\text { villages. Among adolescents from } \\
\text { unrecognized villages, especially } \\
\text { adolescents living in an unrecognized } \\
\text { village with demolitions, a stronger SOC } \\
\text { was linked to stronger emotional } \\
\text { reactions }\end{array}$ \\
\hline 4. Aitcheson et al. & 2017 & Gaza & $\begin{array}{l}11 \text { th }-12 \text { th grade } \\
\text { Palestinians in refugee } \\
\text { camps }\end{array}$ & $\begin{array}{l}\text { Depression, anxiety, } \\
\text { coping skills, self- } \\
\text { regulation, optimism, } \\
\text { parenting style, family } \\
\text { sense of coherence, } \\
\text { national identity, ethnic } \\
\text { identity }\end{array}$ & $\begin{array}{l}\text { Adolescents with stronger national } \\
\text { identity, stronger family SOC, greater } \\
\text { self-regulation, and more optimism } \\
\text { reported less severe depressive and } \\
\text { anxious symptoms. Age, optimism, } \\
\text { family SOC, ethnic identity, self- } \\
\text { regulation, and coping skills were all } \\
\text { significant predictors of resilience }\end{array}$ \\
\hline 5. Barni \& Danioni & 2016 & Italy & $\begin{array}{l}\text { Italian adolescents } \\
\text { between } 14 \text { and } \\
19 \text { years old }\end{array}$ & Values, SOC & $\begin{array}{l}\text { Adolescents' conservative and self- } \\
\text { transcendent values were the most } \\
\text { important predictors of their SOC. The } \\
\text { greater the importance placed on } \\
\text { conservatism and self-transcendence, the } \\
\text { stronger the confidence in the perception } \\
\text { that problems to be faced are clear, } \\
\text { manageable, and worthy of commitment } \\
\text { and engagement }\end{array}$ \\
\hline $\begin{array}{l}\text { 6. Braun-Lewensohn } \\
\text { et al. }\end{array}$ & 2015 & Israel & $\begin{array}{l}\text { Jewish and Arab } \\
\text { adolescents aged } \\
14-19\end{array}$ & $\begin{array}{l}\text { SOC, community SOC, } \\
\text { participation in } \\
\text { extra-curricular activities, } \\
\text { exposure to violence }\end{array}$ & $\begin{array}{l}\text { Jewish adolescents reported significantly } \\
\text { stronger SOC and community } \\
\text { SOC. They participated more in } \\
\text { extra-curricular activities and were more } \\
\text { exposed to and victimized by violence. } \\
\text { While SOC was an asset among both } \\
\text { groups, participation in extra-curricular } \\
\text { activities was an asset only for the Arab } \\
\text { youth }\end{array}$ \\
\hline
\end{tabular}


Table 16.1 (continued)

\begin{tabular}{|c|c|c|c|c|c|}
\hline Author & Year & Place & Population & Variables & Results \\
\hline 7. Braun-Lewensohn & 2016 & Israel & $\begin{array}{l}16-18 \text { year olds during } \\
\text { a social protest }\end{array}$ & $\begin{array}{l}\text { Values, SOC, social } \\
\text { responsibility, civic } \\
\text { efficacy, hope }\end{array}$ & $\begin{array}{l}\text { Values and SOC explained civic } \\
\text { engagement, while only universal and } \\
\text { collective in-group values and civic } \\
\text { engagement directly explained citizens' } \\
\text { efficacy }\end{array}$ \\
\hline $\begin{array}{l}\text { 8. Braun-Lewensohn } \\
\text { et al. }\end{array}$ & 2017 & Israel & $\begin{array}{l}\text { Secular Jewish, } \\
\text { religious Jewish and } \\
\text { Bedouin Arab } \\
\text { adolescents aged } \\
12-18\end{array}$ & SOC, hope & $\begin{array}{l}\text { Religious Jews reported the strongest } \\
\text { SOC and Bedouin Arabs reported the } \\
\text { strongest hope. In both Jewish groups, } \\
\text { significant correlations were found } \\
\text { between the expectation component and/ } \\
\text { or global hope and SOC. However, no } \\
\text { links were found between global hope or } \\
\text { its components or dimensions and SOC } \\
\text { among the Bedouin Arab group }\end{array}$ \\
\hline $\begin{array}{l}\text { 9. Braun-Lewensohn } \\
\text { et al. }\end{array}$ & 2018 & Israel & $\begin{array}{l}\text { Bedouin Arab } \\
\text { adolescents, } \\
14-18 \text { years old, in } \\
2010 \text { and } 2015\end{array}$ & SOC, anxiety, anger & $\begin{array}{l}\text { In the } 2010 \text { sample, unlike in many } \\
\text { stable Western societies, the stronger the } \\
\text { SOC, the more severe the stress } \\
\text { reactions. However, in } 2015 \text {, the results } \\
\text { resembled those reported in Western } \\
\text { cultural settings and the stronger the } \\
\text { SOC, the fewer symptoms of stress were } \\
\text { reported }\end{array}$ \\
\hline $\begin{array}{l}\text { 10. Braun- } \\
\text { Lewensohn \& } \\
\text { Al-Said }\end{array}$ & 2018 & Greece & $\begin{array}{l}\text { Syrian refugee } \\
\text { adolescents aged } \\
13-18\end{array}$ & $\begin{array}{l}\text { Exposure to war, } \\
\text { appraisal of danger, } \\
\text { receiving aid, SOC, } \\
\text { wishes and expectations, } \\
\text { internalizing and } \\
\text { externalizing problems }\end{array}$ & $\begin{array}{l}\text { Boys, younger adolescents, and those } \\
\text { who had more recently arrived in the } \\
\text { refugee camp reported stronger } \\
\text { SOC. The amount of time spent in the } \\
\text { refugee camp, gender, exposure to war } \\
\text { situations, and appraisal of danger all } \\
\text { contributed to the explained variance in } \\
\text { the different psychological problems. } \\
\text { However, SOC mediated the } \\
\text { relationships between all of the } \\
\text { sociodemographic and situational } \\
\text { variables and the examined } \\
\text { psychological problems }\end{array}$ \\
\hline 11. Carneiro et al. & 2017 & Brazil & $\begin{array}{l}29 \text { adolescents with } \\
\text { MPS and } 29 \\
\text { adolescents without } \\
\text { MPS, and their } \\
\text { mothers }\end{array}$ & SOC, MPS & $\begin{array}{l}\text { The SOC of the mothers of adolescents } \\
\text { with MPS was associated with the } \\
\text { adolescents' experiences with dental } \\
\text { caries. Improving mothers' SOC should } \\
\text { contribute to a better quality of life for } \\
\text { their children }\end{array}$ \\
\hline 12. da Costa et al. & 2017 & Brazil & $12-15$ years & $\begin{array}{l}\text { SOC, self-perceived } \\
\text { dental aesthetics, Dental } \\
\text { Aesthetic Index }\end{array}$ & $\begin{array}{l}\text { SOC was associated with self-perceived } \\
\text { dental aesthetics. Among the adolescents } \\
\text { with no need for orthodontic treatment, } \\
\text { those with a low SOC perceived their } \\
\text { dental aesthetics more negatively than } \\
\text { those with high levels of SOC; SOC } \\
\text { being higher in the younger }\end{array}$ \\
\hline 13. Elfassi et al. & 2016 & Israel & $\begin{array}{l}\text { 8th-11th grade from } \\
\text { three communities }\end{array}$ & $\begin{array}{l}\text { Community SOC, } \\
\text { involvement in risk } \\
\text { behaviors }\end{array}$ & $\begin{array}{l}\text { Community SOC is a significant } \\
\text { protective factor that could be related to } \\
\text { reduced involvement in risk behaviors }\end{array}$ \\
\hline 14. El-Shahawy et al. & 2015 & $\begin{array}{l}\text { USA, } \\
\text { California }\end{array}$ & $\begin{array}{l}\text { Adolescents attending } \\
\text { high school }\end{array}$ & $\begin{array}{l}\text { SOC, smoking behavior, } \\
\text { smoking expectations }\end{array}$ & $\begin{array}{l}\text { SOC was correlated with baseline } \\
\text { cigarette smoking and next-year smoking } \\
\text { expectation. SOC did not predict change } \\
\text { in cigarette smoking or change in } \\
\text { next-year smoking }\end{array}$ \\
\hline
\end{tabular}


Table 16.1 (continued)

\begin{tabular}{|c|c|c|c|c|c|}
\hline Author & Year & Place & Population & Variables & Results \\
\hline 15. Evans \& Davis & 2018 & $\begin{array}{l}\text { USA, } \\
\text { Nevada }\end{array}$ & $\begin{array}{l}30 \text { American Indian } \\
\text { (AI) youth } \\
14-18 \text { years old }\end{array}$ & $\begin{array}{l}\text { SOC, psychological } \\
\text { problems, historical loss }\end{array}$ & $\begin{array}{l}\text { Higher levels of SOC predicted fewer } \\
\text { historical trauma-related symptoms. } \\
\text { SOC may enhance AI youth's sense of } \\
\text { belonging by countering the effects of } \\
\text { thwarted belongingness }\end{array}$ \\
\hline $\begin{array}{l}\text { 16. Garcia-Moya } \\
\text { et al. }\end{array}$ & 2014 & Spain & Spanish adolescents & $\begin{array}{l}\text { Bullying victimization, } \\
\text { physical and } \\
\text { psychological symptoms, } \\
\text { SOC }\end{array}$ & $\begin{array}{l}\text { Weak-SOC adolescents were } \\
\text { significantly more likely to be bullied. In } \\
\text { addition, among weak-SOC adolescents, } \\
\text { there was a significant association } \\
\text { between having been bullied and } \\
\text { physical and psychological symptoms. In } \\
\text { contrast, among strong-SOC adolescents, } \\
\text { having been bullied was not significantly } \\
\text { associated with increased physical } \\
\text { complaints and its effects on } \\
\text { psychological complaints seemed to be } \\
\text { weaker }\end{array}$ \\
\hline 17. Huss et al. & 2018 & Israel & $\begin{array}{l}\text { 14- to 16-year-old } \\
\text { Bedouin youth }\end{array}$ & $\begin{array}{l}\text { Drawing on coping } \\
\text { resources }\end{array}$ & $\begin{array}{l}\text { The findings reveal and concretize a } \\
\text { mismatch between SOC among these } \\
\text { youth and the predominant Western } \\
\text { understanding of coping in terms of } \\
\text { meanings, manageability, and } \\
\text { comprehensibility of coping methods }\end{array}$ \\
\hline 18. Jakobsson & 2014 & Sweden & $\begin{array}{l}\text { 15- to } 18 \text {-year-old } \\
\text { Swedish adolescents }\end{array}$ & $\begin{array}{l}\text { Participation in a sport } \\
\text { club, SOC, and its } \\
\text { components }\end{array}$ & $\begin{array}{l}\text { The teenagers found sports fun and } \\
\text { meaningfulness because they } \\
\text { experienced learning and development. } \\
\text { They found competition challenging, and } \\
\text { they enjoyed the involvement and } \\
\text { engagement with others }\end{array}$ \\
\hline 19. Kalagy et al. & 2017 & Israel & $\begin{array}{l}\text { Ultra-Orthodox and } \\
\text { national religious } \\
\text { adolescents aged } \\
14-18 .\end{array}$ & $\begin{array}{l}\text { Attitudes toward the } \\
\text { military operation, } \\
\text { Attitudes toward the } \\
\text { Israeli-Palestinian } \\
\text { conflict, SOC, anxiety, } \\
\text { anger }\end{array}$ & $\begin{array}{l}\text { SOC was positively related to more wars } \\
\text { Hawkish attitudes among the national } \\
\text { religious group. SOC was negatively } \\
\text { related to peaceful resolution Dovish } \\
\text { attitudes among the ultra-Orthodox } \\
\text { adolescents. In both groups, SOC was } \\
\text { negatively related to anxiety }\end{array}$ \\
\hline 20. Krok & 2015 & Poland & $\begin{array}{l}\text { Older adolescents, } \\
16-20 \text { years old }\end{array}$ & $\begin{array}{l}\text { SOC, optimism, } \\
\text { subjective and } \\
\text { psychological well-being }\end{array}$ & $\begin{array}{l}\text { Direct and indirect effects of SOC on } \\
\text { subjective and psychological well-being } \\
\text { measures were found, suggesting that } \\
\text { optimism served as a partial mediator. } \\
\text { SOC should not be interpreted as an } \\
\text { autonomous resource contributing to a } \\
\text { favorable development of late } \\
\text { adolescents' well-being, but as a factor } \\
\text { that works in connection with } \\
\text { dispositional optimism }\end{array}$ \\
\hline 21. Lage et al. & 2017 & Brazil & Adolescents & $\begin{array}{l}\text { SOC, oral clinical } \\
\text { examinations }\end{array}$ & $\begin{array}{l}\text { Higher mother's SOC and adolescent's } \\
\text { SOC were protective factors against } \\
\text { dental caries among the adolescents }\end{array}$ \\
\hline 22. Latzer et al. & 2019 & Israel & Boys in grades $8-12$ & $\begin{array}{l}\text { SOC, body shape, eating } \\
\text { attitudes, eating disorder }\end{array}$ & $\begin{array}{l}\text { SOC was negatively correlated with } \\
\text { developing an eating disorder }\end{array}$ \\
\hline 23. Lindblom et al. & 2017 & Sweden & $\begin{array}{l}\text { 14- to } 21 \text {-year- olds in } \\
\text { pre-criminal and early } \\
\text { criminal phases }\end{array}$ & $\begin{array}{l}\text { Criminal Thinking Styles } \\
\text { (PICTS), SOC }\end{array}$ & $\begin{array}{l}\text { Cognitive intervention shows promise } \\
\text { for reducing criminal thinking patterns } \\
\text { and increasing SOC, which may have } \\
\text { beneficial effects on the behavior of } \\
\text { young offenders }\end{array}$ \\
\hline
\end{tabular}


Table 16.1 (continued)

\begin{tabular}{|c|c|c|c|c|c|}
\hline Author & Year & Place & Population & Variables & Results \\
\hline 24. Moksnes et al. & 2014 & Norway & $\begin{array}{l}\text { Adolescents, } \\
13-18 \text { years old }\end{array}$ & $\begin{array}{l}\text { Stress, SOC, emotional } \\
\text { symptoms }\end{array}$ & $\begin{array}{l}\text { Girls scored higher than boys in terms of } \\
\text { stress related to peer pressure, home life, } \\
\text { school performance, school/leisure } \\
\text { conflict, and emotional symptoms. } \\
\text { Conversely, boys reported higher SOC } \\
\text { than girls. SOC was strongly and } \\
\text { inversely associated with emotional } \\
\text { symptoms, especially anxiety among } \\
\text { girls. SOC also moderated the } \\
\text { association between stress related to peer } \\
\text { pressure and depressive symptoms } \\
\text { among both genders }\end{array}$ \\
\hline $\begin{array}{l}\text { 25. Moksnes \& } \\
\text { Haugan }\end{array}$ & 2015 & Norway & $\begin{array}{l}\text { Adolescents, } \\
13-18 \text { years old }\end{array}$ & $\begin{array}{l}\text { SOC, life satisfaction, } \\
\text { stress }\end{array}$ & $\begin{array}{l}\text { Boys reported higher scores for SOC and } \\
\text { life satisfaction, whereas girls scored } \\
\text { higher than boys in most of the stressor } \\
\text { domains. There was a significantly } \\
\text { strong and positive association between } \\
\text { SOC and life satisfaction, independent of } \\
\text { age, and each individual stressor }\end{array}$ \\
\hline $\begin{array}{l}\text { 26. Moksnes \& } \\
\text { Lazarewicz }\end{array}$ & 2016 & Norway & $\begin{array}{l}\text { Adolescents, } \\
13-18 \text { years old }\end{array}$ & & $\begin{array}{l}\text { Adolescents aged } 13-14 \text { years had } \\
\text { significantly higher SOC scores than } \\
\text { those aged } 15-16 . \text { A significant positive } \\
\text { association was found between } \\
\text { self-esteem and SOC when controlling } \\
\text { for sex, age, stress, subjective health } \\
\text { complaints, and subjective health. } \\
\text { Neither sex nor age moderated the } \\
\text { relationship between self-esteem and } \\
\text { SOC }\end{array}$ \\
\hline 27. Rizou et al. & 2017 & Greece & $\begin{array}{l}\text { Children, } 10-18 \text { years } \\
\text { old, with epilepsy }\end{array}$ & $\begin{array}{l}\text { Disease characteristics, } \\
\text { perception of the illness, } \\
\text { psychological distress, } \\
\text { sleep problems, somatic } \\
\text { complaints }\end{array}$ & $\begin{array}{l}\text { A brief self-regulation-based intervention } \\
\text { may have beneficial effects for children } \\
\text { and adolescents suffering from epilepsy, } \\
\text { through improvements in coherence, } \\
\text { psychological distress, and sleep } \\
\text { problems }\end{array}$ \\
\hline 28. Shreuder et al. & 2014 & Netherland & $\begin{array}{l}\text { Adolescents and } \\
\text { young adults, } \\
17-22 \text { years old }\end{array}$ & $\begin{array}{l}\text { Semi-structured } \\
\text { interviews to elicit their } \\
\text { experiences from a } \\
\text { salutogenic perspective }\end{array}$ & $\begin{array}{l}\text { Analysis revealed that several on the } \\
\text { youth care farm worked well for the } \\
\text { youngsters and contributed to their } \\
\text { personal development and to their SOC: } \\
\text { the feeling that the world is or can be } \\
\text { meaningful, comprehensible, and } \\
\text { manageable, associated with positive } \\
\text { outcomes in endeavors linked to } \\
\text { improving health and well-being }\end{array}$ \\
\hline 29. Smith et al. & 2015 & USA & $\begin{array}{l}\text { Adolescents aged } \\
11-18 \text { with a sibling } \\
\text { diagnosed with autism }\end{array}$ & $\begin{array}{l}\text { Coping orientation, } \\
\text { relationships, SOC, } \\
\text { psychological problems }\end{array}$ & $\begin{array}{l}\text { The stress of autism spectrum disorder } \\
\text { (ASD) severity and adjustment resources } \\
\text { are related among typically developing } \\
\text { (TD) adolescents who have an autistic } \\
\text { sibling. There was a strong relationship } \\
\text { between TD sibling adjustment and } \\
\text { SOC. A greater number of positive } \\
\text { coping strategies buffered TD sibling } \\
\text { coherence levels when ASD severity } \\
\text { scores were high }\end{array}$ \\
\hline 30. Super et al. & 2018 & Netherland & $\begin{array}{l}\text { Vulnerable youth, } \\
12-23 \text { years old }\end{array}$ & $\begin{array}{l}\text { Behavior, school } \\
\text { performance, subjective } \\
\text { health and well-being, } \\
\text { self-regulation skills, } \\
\text { SOC, sports participation }\end{array}$ & $\begin{array}{l}\text { Sports participation was positively } \\
\text { related to pro-social behavior, subjective } \\
\text { health, well-being, and SOC }\end{array}$ \\
\hline
\end{tabular}


Table 16.1 (continued)

\begin{tabular}{|c|c|c|c|c|c|}
\hline Author & Year & Place & Population & Variables & Results \\
\hline $\begin{array}{l}\text { 31. Ustinavičienė } \\
\text { et al. }\end{array}$ & 2018 & Lithuania & $\begin{array}{l}\text { Adolescents aged } \\
13-18\end{array}$ & $\begin{array}{l}\text { Amount of time spent } \\
\text { playing computer games, } \\
\text { types of games, SOC }\end{array}$ & $\begin{array}{l}\text { Boys and girls aged } 13-15 \text { with a weak } \\
\text { SOC were significantly more likely to } \\
\text { play action or combat computer games } \\
\text { for } 5 \text { or more hours per day, in } \\
\text { comparison to the respondents who had a } \\
\text { strong SOC }\end{array}$ \\
\hline $\begin{array}{l}\text { 32. Vilija \& } \\
\text { Romualdas }\end{array}$ & 2014 & Lithuania & 8th graders & $\begin{array}{l}\text { Posttraumatic stress } \\
\text { (PTS) symptoms, daily } \\
\text { consumption of } \\
\text { unhealthy foods, physical } \\
\text { inactivity, smoking, SOC }\end{array}$ & $\begin{array}{l}\text { All lifetime traumatic events were } \\
\text { associated with PTS symptoms, as well } \\
\text { as were consumption of unhealthy foods. } \\
\text { SOC weakened the strength of those } \\
\text { associations }\end{array}$ \\
\hline 33. Wadsby et al. & 2014 & Sweden & High-school students & $\begin{array}{l}\text { Parental bonding, } \\
\text { psychiatric symptoms, } \\
\text { SOC }\end{array}$ & $\begin{array}{l}\text { SOC was higher among teens with } \\
\text { alternating residences and teens living } \\
\text { with both parents, but it was lower } \\
\text { among those living with a single parent }\end{array}$ \\
\hline 34. Wang et al. & 2014 & Australia & $\begin{array}{l}\text { Adolescents with heart } \\
\text { disease, } 12-20 \text { years } \\
\text { old }\end{array}$ & $\begin{array}{l}\text { Quality of life, } \\
\text { adolescents' knowledge } \\
\text { of their cardiac } \\
\text { condition, anxiety, } \\
\text { depression, perceived } \\
\text { social support, Life } \\
\text { Orientation, SOC }\end{array}$ & $\begin{array}{l}\text { Health-related quality of life was found } \\
\text { to be positively correlated with low } \\
\text { levels of anxiety and depression, a good } \\
\text { understanding of their cardiac condition, } \\
\text { feelings of optimism, adequate social } \\
\text { support, and a strong SOC }\end{array}$ \\
\hline 35. Würtz et al. & 2015 & Denmark & 7th and 8 th graders & $\begin{array}{l}\text { Use of over-the-counter } \\
\text { painkillers, pain, } \\
\text { well-being, friends, SOC }\end{array}$ & $\begin{array}{l}\text { Girls with a weak SOC (the lowest first } \\
\text { quartile) had a significantly increased } \\
\text { risk of receiving unemployment benefits, } \\
\text { social assistance and disability benefits, } \\
\text { compared with girls with a strong } \\
\text { SOC. For boys, only minor protective } \\
\text { and non-significant differences were } \\
\text { found }\end{array}$ \\
\hline 36. Xu et al. & 2019 & China & $\begin{array}{l}\text { Middle- and high- } \\
\text { school students }\end{array}$ & $\begin{array}{l}\text { Socioeconomic status, } \\
\text { maternal care and } \\
\text { control, SOC, depression }\end{array}$ & $\begin{array}{l}\text { Socioeconomic status, maternal care, and } \\
\text { adolescent SOC were positively related } \\
\text { to each other and negatively related to } \\
\text { adolescent depressive symptoms. } \\
\text { Socioeconomic status was associated } \\
\text { with adolescent depressive symptoms } \\
\text { indirectly through maternal care } \\
\text { separately, as well as through maternal } \\
\text { care and adolescent SOC sequentially }\end{array}$ \\
\hline
\end{tabular}

\section{Adaptations of the SOC Questionnaires}

Based on the original SOC questionnaire (Antonovsky, 1983), several researchers have examined the adaptability of the questionnaire to adolescent populations. For example, the adolescent sense of coherence scale (Antonovsky \& Sagy, 1986) was adjusted to fit adolescents' characteristics, that is, development of self-identity, orientation to one's self society, confusion, unpredictable changes, close emotional ties with parents for the development of open communication, stability of the community, etc. Several items were removed from the original 29-item scale, and others were rephrased to make sure that adolescents understand the items (Antonovsky
\& Sagy, 1986), ending up with the final version of 13 items which is considered as a single factor and not the three separate components-meaningfulness, comprehensibility, and manageability (Hagquist \& Andrich, 2004). Many studies have used this scale, and reliability proved to be very $\operatorname{good}(\alpha \approx 0.80)$. Another approach to the adaptation of the scale to the adolescence developmental stage was based on the use of the child version (CSOC) without the examples and distractors for younger children. The description of the CSOC can be found in the chapter on children (Margalit \& Efrati, 1996). The adolescence adaptation from the CSOC consisted of 16 items (e.g., "When I want something I'm sure I'll get it"; "When I need help there is someone around 
to help me"), on a five-point Likert-type scale ranging from 1 (never) to 5 (always). A Cronbach's alpha of 0.78 was obtained (Levi et al., 2014).

\section{The SOC Construct During Adolescence}

The stability question regarding SOC accompanied this construct since the beginning of research about it. Antonovsky and Sagy (1986) argued that SOC should be strengthening during adolescence and stabilized toward the end of this developmental period. However, studies that addressed the issue of age and the stability of SOC revealed inconsistencies (Apers et al., 2013; Ayo-Yusuf et al., 2008; Garcia-Moya et al., 2013a, b, c, d; Kristensson \& Öhlund, 2005; Moksnes et al., 2012). Indeed, Eriksson and Lindström (2007) stated that SOC is likely to vary during adolescence due to developmental changes, transitions, and challenges. While some researchers did not find differences among various age groups (Honkinen et al., 2008) and claimed the existence of SOC stability during adolescence (Kröninger-Jungaberle \& Grevenstein, 2013), others focused on the variability between groups of adolescents between younger and older adolescents (Garcia-Moya et al., 2013a, b, c, d) as well as between groups with strong versus weak scores of SOC. The group with a weaker SOC reported more variability in its SOC scores (Buddeberg-Fischer et al., 2001).

Moreover, during periods of political violence, studies have shed light on the impacts of fragile periods and documented a drop in SOC levels during acute stress situations. However, once the acuteness is over, the SOC gains back its strengths (Braun-Lewensohn et al., 2013). Nevertheless, when adolescents face chronic states of stress, such as longitudinal missile attacks, the deterioration of the SOC remained stable over time (Braun-Lewensohn \& Sagy, 2010).

Other demographic characteristics, apart from age, have significant roles in the determination of the SOC levels. Gender differences were examined, and many studies showed that the SOC scores of boys were higher than the scores of girls (Apers et al., 2013; Dorri et al., 2010; Evans et al., 2010; Kristensson \& Öhlund, 2005; Moksnes et al., 2011, 2012; Nio, 2010). Also, socioeconomic status plays an important role in the SOC prediction. Thus, higher levels of parents' education (Feldt et al., 2005; Geckova et al., 2010; Ristkari et al., 2009), higher economic status (Geckova et al., 2010), and living with two parents (Ayo-Yusuf et al., 2009) have been important indicators of stronger SOC. Lastly, membership in a minority group in different cultures around the world predicted weaker SOC scores than those of majority groups (Braun-Lewensohn, 2014; BraunLewensohn \& Sagy, 2011a, b; Glanz et al., 2005).

\section{SOC, Health, Mental Health, and Psychosocial Behavior}

Examining the various studies, we found that the relations of health, mental health, and psychosocial behaviors with SOC were explored. More specifically, researchers investigated the SOC as a predictor of health outcomes, mental health, and diverse health-promoting behaviors during adolescence.

Several studies examined the relations between the SOC and general health (Eriksson \& Lindström, 2006; Nilsson et al., 2003). Stronger SOC was related to better-perceived health, while weaker SOC was related to medication use. Moreover, SOC was negatively related to reported health problems (Blom et al., 2010; Garcia-Moya et al., 2013a, b, c, d; Geckova et al., 2010; Honkinen et al., 2005; Koushede \& Holstein, 2009; Mattila et al., 2011; Modin et al., 2011; Moksnes et al., 2011; Myrin \& Lagerström, 2006).

Other examinations related to health focused on groups with specific health problems. For example, surprisingly, adolescents with heart problems were found to have a stronger SOC compared to healthy adolescents. These results were explained by the fact that youngsters with such chronic disease have learned to cope with their problem, which increased their manageability, besides having existential implications that increased their meaningfulness. Moreover, a supportive home environment experienced by these adolescents emphasizes specific life events as being more comprehensible, manageable, and meaningful; hence, nurtured feelings of SOC (Luyckx et al., 2012). More expected results were found for adolescents with epilepsy where a weaker SOC was found in the long run, reflecting the experience of losing control during seizures and difficulty in assessing when to expect the next seizure. Following this line, those adolescents with no seizures had a stronger SOC (Gauffin et al., 2010).

Mental health has been the focus of numerous studies that examined diverse outcomes. Stress-related outcomes such as anxiety, anger, depression, psychological distress, and other emotional and internalizing or externalizing problems were examined in the context of political violence (BraunLewensohn \& Sagy, 2010, 2011a, b; Sagy \& BraunLewensohn, 2009) and with regard to challenging and extreme life events such as child abuse (Gustafsson et al., 2010) or juvenile delinquency (Koposov et al., 2003). However, adolescents were also examined during regular daily life with "normal" life stressors, such as academic, school, or peer pressure as well as family conflicts (Moksnes et al., 2012, 2013; Nielsen \& Hansson, 2007; Ristkari et al., 2009; Simonsson et al., 2008). All these studies confirm that the SOC can be considered a resilience factor. It can be concluded that a strong SOC predicts reduced stress and decreased internalizing or/and externalizing problems. 
Moreover, examining the relationships of SOC with $p s y$ chosocial behaviors even strengthens the consideration of SOC as a resilient factor. Accordingly, results of various studies showed that adolescents with stronger SOC reported a healthier lifestyle, a better quality of life, and well-being (Honkinen et al., 2009; Neuner et al., 2011). The healthy lifestyle is related, on the one hand, to physical activities and exercises (Bronikowski, 2010) and, on the other hand, to smoking habits, alcohol abuse (Garcia-Moya et al., 2013a, b, c, d, 2013a; Myrin \& Lagerström, 2006; Nielsen \& Hansson, 2007), and eating habits (Myrin \& Lagerström, 2006). Similarly, the relations between SOC and oral behavior (e.g., toothbrush habits) were reported. Stronger SOC was linked to lower gingivitis, more willingness to change toothbrush habits, and especially increased tooth brushing (e.g., AyoYusuf et al., 2008, 2009; Dorri et al., 2010).

\section{Ecological Contexts: Family, School, Peers, and Community}

Ecological contexts (Bronfenbrenner, 1977, 1979; Bronfenbrenner \& Morris, 2006) extend the consideration from a focus on the personal level to awareness and sensitization to contextual characteristics and systemic consideration such as the families, schools, and communities. Several family-related factors were examined in relation to the SOC. For example, open family communication (GarciaMoya et al., 2013a, b, c, d; Marsh et al., 2007), focused parenting style (Garcia-Moya et al., 2013a, b, c, d), and parents' knowledge regarding their children activities (Garcia-Moya et al., 2013a, b, c, d) were considered positive contributors to the development of a strong SOC. In addition, child-centered parenting during adolescence (examined within a longitudinal paradigm) predicted a stronger SOC at adulthood (Feldt et al., 2005).

In addition to examining family contexts and factors which could enhance or reduce personal SOC, few studies also related to family sense of coherence as another source to rely on when facing difficulties and/or stressful situations. Likewise the personal SOC, it was found that also family SOC is a resilient factor, and adolescents with stronger family SOC reported reduced stress (Sagy \& BraunLewensohn, 2009; Sagy \& Dotan, 2001).

Another important ecological system is school. While the family dimension produced mainly studies that pinpointed attention at the contribution of family characteristics to the development of SOC, studies of schools focused attention on outcomes, examining the adolescents' achievement and adjustment, and their relationship to SOC as a mediation factor. Within the educational systems, a stronger SOC predicted high grades and enhanced academic motivation and success. Lower stress levels were also reported as related to stronger SOC (Honkinen et al., 2005; Kristensson \& Öhlund, 2005; Lackaye \& Margalit, 2006). Moreover, stronger SOC was linked to social competence (Mattila et al., 2011; Moksnes et al., 2011).

The school system provides a unique opportunity to look at particular populations with regard to SOC. Adolescents with learning disabilities are an additional example of the importance of the SOC (Idan \& Margalit, 2014; Lackaye \& Margalit, 2006). These youngsters are identified by their chronic academic challenges emerging from neurodevelopmental difficulties. Their difficulties at school systems remain a continuous source for increased stress, endless day-to-day struggling with age-appropriate academic roles, and with social and emotional consequences. Indeed their sources of stress are not dramatic, but their lasting impact is expressed in weaker SOC. Studies placed the SOC as a mediator of hopeful thinking, predicting adjustment and effort investment in school. The adolescents' systems, such as families, schools, and communities, may further clarify the important role of the SOC and the factors that predict its development.

The focus on peer relations and community atmosphere produced studies that explored these factors as predictors of SOC development. An additional group of studies explored SOC as a collective construct contributing to the mental health of adolescents. Exploring SOC as a dependent variable, it seems that social support (Marsh et al., 2007), neighborhood or community cohesion (Garcia-Moya et al., 2013a, b, c, d; Marsh et al., 2007; Peled et al., 2013), and success in school (Garcia-Moya et al., 2013a, b, c, d) are all constructive in the development of strong SOC.

To expand the measurement of the SOC from the personal to the collective level, the sense of community coherence instrument was developed, which includes the components of comprehensibility, manageability, and meaningfulness (Braun-Lewensohn, 2014; Braun-Lewensohn \& Sagy, 2011b; Peled et al., 2013). Comprehensibility refers to the sense of predictability, safety, and security felt by members of the community and the extent to which that community is understandable. A community's manageability expresses its ability to assist its members, via treatment providers and group programs, among others, in times of crisis and distress. Lastly, the higher the level of meaningfulness among the members of a community, the abler they are to express themselves, and the higher the likelihood that they will feel satisfied with and challenged and interested by what the community has to offer them (Braun-Lewensohn \& Sagy, 2011b). Recent studies showed that indeed the sense of community coherence is another source of support for coping during adolescence when facing acute or chronic types of stress, especially among collectivist cultures (BraunLewensohn, 2014; Braun-Lewensohn \& Sagy, 2011b; Peled et al., 2013). 


\section{Conclusions, Implications, and Directions for Future Research}

This chapter focused on the sense of coherence and salutogenesis during the developmental period of adolescence. While in many ways, adolescents appear to function similarly to adults, numerous cognitive, biological, and behavioral processes are formed and shaped on the path to maturity and normative adulthood.

A recent review on salutogenesis and the concept of SOC examined the influence of different factors such as gender and age as well as different developmental contexts (family, school, peers, and neighborhood) on the development of SOC (Rivera et al., 2013). In our current review, we extended conceptualization and research results regarding SOC during this important developmental period of adolescence within a different orientation. Mainly, we addressed how the SOC questionnaire was adopted to fit adolescent populations, as well as the clarifying ways how SOC is linked to different health, mental health, and psychosocial behaviors in different ecological contexts. We can conclude that the review of studies from around the world in the last decade demonstrated that personal and systemic (i.e., family and community) SOC are important resources for coping with a wide variety of stressful situations. The survey of the studies shows that the SOC may be considered as a protective factor for adolescents in different cultures. During adolescence, the SOC may contribute to moderating and mediating stress experiences and may also play a protective role, similar to that of the mature adult SOC.

The educational and community implications of the current consideration of the $\mathrm{SOC}$ as a critical resource call for the sensitizing educators and community workers to the importance of the salutogenic construct. Future empowering programs should be guided by this construct, leading to the development of prevention/inoculation to stress planning as well as programs promoting positive psychosocial and healthy behaviors and academic success.

Our review raises several directions for future research in the field of salutogenesis and the sense of coherence during adolescence. Despite developments, there are still some issues that require attention. This includes the role of family coherence as a protective factor for health and mental health, for success in school, and psychosocial behaviors that determine their relationships and their attitudes toward each other. Moreover, non-western cultural groups were less studied in this context. When studied, some questions regarding the universality of the concept of SOC were raised (Braun-Lewensohn \& Sagy, 2011a). Thus, it seems important to examine this issue further. We should focus on the meanings of sense of coherence in such cultures as well as the understanding of the questionnaire and the implication of SOC in such societies.

\section{References}

Abu-Kaf, S., \& Braun-Lewensohn, O. (2019). Coping resources and stress reactions among Bedouin Arab adolescents during three military operations. Psychiatry Research, 273, 559-566.

Abu-Kaf, S., Braun-Lewensohn, O., \& Kalagy, T. (2017). Youth in the midst of escalated political violence: Sense of coherence and hope among Jewish and Bedouin Arab adolescents. Child and Adolescent Psychiatry and Mental Health, 11(1), 42.

Aitcheson, R. J., Abu-Bader, S. H., Howell, M. K., Khalil, D., \& Elbedour, S. (2017). Resilience in Palestinian adolescents living in Gaza. Psychological Trauma Theory Research Practice and Policy, 9(1), 36.

Aldwin, C. M., Levenson, M. R., \& Spiro, A. (1994). Vulnerability and resilience to combat exposure: Can stress have lifelong effects? Psychology and Aging, 9(1), 34.

Al-Said, H., Braun-Lewensohn, O., \& Sagy, S. (2018). Sense of coherence, hope, and home demolition are differentially associated with anger and anxiety among Bedouin Arab adolescents in recognized and unrecognized villages. Anxiety, Stress, and Coping, $31(4), 475-485$.

Antonovsky, A. (1983). The sense of coherence: Development of a research instrument. WS Schwartz Research Center for Behavioral Medicine, Tel Aviv University, Newsletter and Research Reports $1: 1-11$.

Antonovsky, A. (1987). Unraveling the mystery of health: How people manage stress and stay well. Jossey-Bass.

Antonovsky, H., \& Sagy, S. (1986). The development of a sense of coherence and its impact on responses to stress situations. The Journal of Social Psychology, 126(2), 213-226.

Apers, S., Moons, P., Goossens, E., Luyckx, K., Gewillig, M., Bogaerts, K., \& Budts, W. (2013). Sense of coherence and perceived physical health explain the better quality of life in adolescents with congenital heart disease. European Journal of Cardiovascular Nursing, 12(5), 475-483.

Ayo-Yusuf, O. A., Reddy, P. S., \& Van Den Borne, B. W. (2008) Adolescents' sense of coherence and smoking as longitudinal predictors of self-reported gingivitis. Journal of Clinical Periodontology, 35(11), 931-937.

Ayo-Yusuf, O. A., Reddy, P. S., \& Van Den Borne, B. W. (2009). Longitudinal association of adolescents' sense of coherence with toothbrushing using an integrated behaviour change model. Community Dentistry and Oral Epidemiology, 37(1), 68-77.

Barni, D., \& Danioni, F. (2016). Adolescents' basic personal values and sense of coherence. Personality and Individual Differences, 102, 46-50.

Blakemore, S.-J., \& Mills, K. L. (2014). Is adolescence a sensitive period for sociocultural processing? Annual Review of Psychology, 65(1). https://doi.org/10.1146/annurev-psych-010213-115202

Blom, E. C. H., Serlachius, E., Larsson, J. O., Theorell, T., \& Ingvar, M. (2010). Low sense of coherence (SOC) is a mirror of general anxiety and persistent depressive symptoms in adolescent girls - A cross-sectional study of a clinical and a non-clinical cohort. Health and Quality of Life Outcomes, 8(1), 58.

Braun-Lewensohn, O. (2014). Coping resources and stress reactions among three cultural groups one year after a natural disaster. Clinical Social Work Journal, 42(4), 366-374.

Braun-Lewensohn, O. (2016). Sense of coherence, values, youth involvement, civic efficacy and hope: Adolescents during social protest. Social Indicators Research, 128(2), 661-673.

Braun-Lewensohn, O., Abu-Kaf, S., \& Kalagy, T. (2017). Are 'sense of coherence' and 'hope' related constructs? Examining these concepts in three cultural groups in Israel. The Israel Journal of Psychiatry and Related Sciences, 54(2), 17-24. 
Braun-Lewensohn, O., \& Al-Said, H. (2018). Syrian adolescent refugees: How do they cope during their stay in refugee camps? Frontiers in Psychology, 9. https://doi.org/10.3389/fpsyg.2018.01258

Braun-Lewensohn, O., Alziadneh, S., \& Eisha, H. (2015). Coping resources and extra-curricular activity as explanatory factors of exposure to violence: Comparing Jewish and Arab youth in Israel. The Journal of Primary Prevention, 36(3), 167-176. https://doi. org/10.1007/s10935-015-0385-4

Braun-Lewensohn, O., Huss, E., Al-Said, H., \& Ganayeim, H. (2018). Bedouin adolescents: Are their coping resources stable over time? In K. A. Moore \& P. Buchwald (Eds.), Stress and anxiety. Theories and realities (pp. 97-105). Logos.

Braun-Lewensohn, O., \& Sagy, S. (2010). Sense of coherence, hope and values among adolescents under missile attacks: A longitudinal study. International Journal of Children's Spirituality, 15(3), 247-260.

Braun-Lewensohn, O., \& Sagy, S. (2011a). Coping resources as explanatory factors of stress reactions during missile attacks: Comparing Jewish and Arab adolescents in Israel. Community Mental Health Journal, 47(3), 300-310.

Braun-Lewensohn, O., \& Sagy, S. (2011b). Salutogenesis and culture: Personal and community sense of coherence among adolescents belonging to three different cultural groups. International Review of Psychiatry, 23(6), 533-541.

Braun-Lewensohn, O., Sagy, S., \& Roth, G. (2011). Coping strategies as mediators of the relationship between sense of coherence and stress reactions: Israeli adolescents under missile attacks. Anxiety, Stress, and Coping, 24(3), 327-341.

Braun-Lewensohn, O., Sagy, S., Sabato, H., \& Galili, R. (2013). Sense of coherence and sense of community as coping resources of religious adolescents before and after the disengagement from the Gaza Strip. The Israel Journal of Psychiatry and Related Sciences, 50(2), 110-117.

Bronfenbrenner, U. (1977). Toward an experimental ecology of human development. The American Psychologist, 32(7), 513.

Bronfenbrenner, U. (1979). The ecology of human development. Harvard University Press.

Bronfenbrenner, U., \& Morris, P. A. (2006). The bioecological model of human development. In R. M. L. W. Damon (Ed.), Handbook of child psychology (Theoretical models of human development) (Vol. 1, 6th ed., pp. 793-828). Wiley.

Bronikowski, M. (2010). Is sense of coherence needed to keep youth physically active? Medicina Dello Sport; Rivista di Fisiopatologia Dello Sport, 63(4), 465-483.

Buddeberg-Fischer, B., Klaghofer, R., \& Schnyder, U. (2001). Sense of coherence in adolescents. Sozial- und Präventivmedizin, 46(6), 404-410.

Carneiro, N. C., Duda Deps, T., Campos França, E., Ribeiro Valadares, E., Almeida Pordeus, I., \& Borges-Oliveira, A. C. (2017). Oral health of children and adolescents with mucopolysaccharidosis and mother's sense of coherence. Special Care in Dentistry, 37(5), $223-229$.

Casey, B. J., \& Caudle, K. (2013). The teenage brain: Self-control. Current Directions in Psychological Science, 22(2), 82-87.

da Costa, A. C., Rodrigues, F. S., da Fonte, P. P., Rosenblatt, A., Innes, N. P. T., \& Heimer, M. V. (2017). Influence of sense of coherence on adolescents' self-perceived dental aesthetics: A cross-sectional study. BMC Oral Health, 17(1), 117.

Damon, W. (2004). What is positive youth development? The Annals of the American Academy of Political and Social Science, 591(1), $13-24$.

Dorri, M., Sheiham, A., Hardy, R., \& Watt, R. (2010). The relationship between sense of coherence and toothbrushing behaviours in Iranian adolescents in Mashhad. Journal of Clinical Periodontology, 37(1), $46-52$.
Elfassi, Y., Braun-Lewensohn, O., Krumer-Nevo, M., \& Sagy, S. (2016). Community sense of coherence among adolescents as related to their involvement in risk behaviors. Journal of Community Psychology, 44(1), 22-37.

El-Shahawy, O., Sun, P., Tsai, J. Y. K., Rohrbach, L. A., \& Sussman, S. (2015). Sense of coherence and tobacco use myths among adolescents as predictors of at-risk youth cigarette use. Substance Use \& Misuse, 50(1), 8-14.

Evans, W., \& Davis, B. (2018). Exploring the relationship between sense of coherence and historical trauma among American Indian youth. American Indian and Alaska Native Mental Health Research (online), 25(3), 1-25.

Evans, W. P., Marsh, S. C., \& Weigel, D. J. (2010). Promoting adolescent sense of coherence: Testing models of risk, protection, and resiliency. Journal of Community and Applied Social Psychology, 20(1), 30-43.

Eriksson, M., \& Lindström, B. (2006). Antonovsky's sense of coherence scale and the relation with health: A systematic review. Journal of Epidemiology and Community Health, 60(5), 376-381.

Eriksson, M., \& Lindström, B. (2007). Antonovsky's sense of coherence scale and its relation with quality of life: A systematic review. Journal of Epidemiology and Community Health, 61(11), 938-944.

Feldt, T., Kokko, K., Kinnunen, U., \& Pulkkinen, L. (2005). The role of family background, school success, and career orientation in the development of sense of coherence. European Psychologist, 10(4), 298-308.

García-Moya, I., Jiménez-Iglesias, A., \& Moreno, C. (2013a). Sense of coherence and substance use in Spanish adolescents. Does the effect of SOC depend on patterns of substance use in their peer group? Adicciones, 25(2), 109.

García-Moya, I., Moreno, C., \& Jiménez-Iglesias, A. (2013b). Understanding the joint effects of family and other developmental contexts on the sense of coherence (SOC): A person-focused analysis using the classification tree. Journal of Adolescence, 36(5), 913-923.

García-Moya, I., Moreno, C., \& Braun-Lewensohn, O. (2013c). Neighbourhood perceptions and sense of coherence in adolescence. The Journal of Primary Prevention, 34(5), 371-379.

García-Moya, I., Rivera, F., \& Moreno, C. (2013d). School context and health in adolescence: The role of sense of coherence. Scandinavian Journal of Psychology, 54(3), 243-249.

García-Moya, I., Suominen, S., \& Moreno, C. (2014). Bullying victimization prevalence and its effects on psychosomatic complaints: Can sense of coherence make a difference? The Journal of School Health, 84(10), 646-653.

Garnefski, N., Kraaij, V., \& Spinhoven, P. (2001). Negative life events, cognitive emotion regulation and emotional problems. Personality and Individual Differences, 30(8), 1311-1327.

Gauffin, H., Landtblom, A. M., \& Räty, L. (2010). Self-esteem and sense of coherence in young people with uncomplicated epilepsy: A 5-year follow-up. Epilepsy \& Behavior, 17(4), 520-524.

Geckova, A. M., Tavel, P., van Dijk, J., Abel, T., \& Reijneveld, S. (2010). Factors associated with educational aspirations among adolescents: Cues to counteract socioeconomic differences. BMC Public Health, 10(1), 154.

Glanz, K., Maskarinec, G., \& Carlin, L. (2005). Ethnicity, sense of coherence, and tobacco use among adolescents. Annals of Behavioral Medicine, 29(3), 192-199.

Gustafsson, P. E., Nelson, N., \& Gustafsson, P. A. (2010). Diurnal cortisol levels, psychiatric symptoms and sense of coherence in abused adolescents. Nordic Journal of Psychiatry, 64(1), 27-31.

Hagquist, C., \& Andrich, D. (2004). Is the sense of coherenceinstrument applicable on adolescents? A latent trait analysis using Rasch-modelling. Personality and Individual Differences, 36(4), 955-968. 
Honkinen, P. L., Aromaa, M., Suominen, S., Rautava, P., Sourander, A., Helenius, H., \& Sillanpää, M. (2009). Early childhood psychological problems predict a poor sense of coherence in adolescents: A 15-year follow-up study. Journal of Health Psychology, 14(4), 587-600.

Honkinen, P. L., Suominen, S., Helenius, H., Aromaa, M., Rautava, P., Sourander, A., \& Sillanpää, M. (2008). Stability of the sense of coherence in adolescence. International Journal of Adolescent Medicine and Health, 20, 85-91.

Honkinen, P. L. K., Suominen, S. B., Välimaa, R. S., Helenius, H. Y., \& Rautava, P. T. (2005). Factors associated with perceived health among 12-year-old school children. Relevance of physical exercise and sense of coherence. Scandinavian Journal of Public Health, 33(1), 35-41.

Huss, E., Braun-Lewensohn, O., \& Ganaim, H. (2018). Using artsbased research to overcome the mismatch between Western and Indigenous forms of coping of Bedouin youth. International Journal of Psychology, 53(S2), 64-71.

Idan, O., \& Margalit, M. (2014). Socioemotional self-perceptions, family climate, and hopeful thinking among students with learning disabilities and typically achieving students from the same classes. Journal of Learning Disabilities, 47(2), 136-152.

Jakobsson, B. (2014). What makes teenagers continue? A salutogenic approach to understanding youth participation in Swedish club sports. Physical Education and Sport Pedagogy, 19(3), 239-252.

Kalagy, T., Braun-Lewensohn, O., \& Abu-Kaf, S. (2017). Youth from fundamentalist societies: What are their attitudes towards war and peace and their relations with anxiety reactions? Journal of Religion and Health, 56(3), 1064-1080. https://doi.org/10.1007/ s10943-017-0358-4

Koposov, R. A., Ruchkin, V. V., \& Eisemann, M. (2003). Sense of coherence: A mediator between violence exposure and psychopathology in Russian juvenile delinquents. The Journal of Nervous and Mental Disease, 191(10), 638-644.

Koushede, V., \& Holstein, B. E. (2009). Sense of coherence and medicine use for headache among adolescents. The Journal of Adolescent Health, 45(2), 149-155.

Kristensson, P., \& Öhlund, L. S. (2005). Swedish upper secondary school pupils' sense of coherence, coping resources and aggressiveness in relation to educational track and performance. Scandinavian Journal of Caring Sciences, 19(1), 77-84.

Krok, D. (2015). Religiousness, spirituality, and coping with stress among late adolescents: A meaning-making perspective. Journal of Adolescence, 45, 196-203.

Kröninger-Jungaberle, H., \& Grevenstein, D. (2013). Development of salutogenetic factors in mental health - Antonovsky's sense of coherence and Bandura's self-efficacy related to Derogatis' symptom check list (SCL-90-R). Health and Quality of Life Outcomes, 11(1), 80 .

Lackaye, T. D., \& Margalit, M. (2006). Comparisons of achievement, effort, and self-perceptions among students with learning disabilities and their peers from different achievement groups. Journal of Learning Disabilities, 39(5), 432-446.

Lage, C. F., Fulgencio, L. B., Corrêa-Faria, P., Serra-Negra, J. M., Paiva, S. M., \& Pordeus, I. A. (2017). Association between dental caries experience and sense of coherence among adolescents and mothers. International Journal of Paediatric Dentistry, 27(5), 412-419.

Latzer, Y., Weinberger-Litman, S. L., Spivak-Lavi, Z., \& Tzischinsky, O. (2019). Disordered eating pathology and body image among adolescent girls in Israel: The role of sense of coherence. Community Mental Health Journal, 55(7), 1246-1252.

Lerner, R. M., \& Benson, P. I. (2003). Developmental assets and assetbuilding communities: Implications for research, policy, and practice. Kluwer Academic/Plenum.
Levi, U., Einav, M., Ziv, O., Raskind, I., \& Margalit, M. (2014). Academic expectation and actual achievement: The roles of hope and effort. European Journal of Psychology of Education, 29(3), 367-386

Lindblom, S., Eriksson, L., \& Hiltunen, A. J. (2017). Evaluation of the cognitive intervention programme 'A New Direction' targeting young offenders in Sweden. Journal of Scandinavian Studies in Criminology and Crime Prevention, 18(2), 176-190.

Luyckx, K., Missotten, L., Goossens, E., \& Moons, P. (2012). Individual and contextual determinants of quality of life in adolescents with congenital heart disease. The Journal of Adolescent Health, 51(2), $122-128$.

Margalit, M., \& Efrati, M. (1996). Loneliness, coherence and companionship among children with learning disorders. Educational Psychologist, 16(1), 69-79.

Marsh, S. C., Clinkinbeard, S. S., Thomas, R. M., \& Evans, W. P. (2007). Risk and protective factors predictive of sense of coherence during adolescence. Journal of Health Psychology, 12(2), 281-284.

Mattila, M. L., Rautava, P., Honkinen, P. L., et al. (2011). Sense of coherence and health behaviour in adolescence. Acta Paediatrica, 100(12), 1590-1595.

Modin, B., Östberg, V., Toivanen, S., \& Sundell, K. (2011). Psychosocial working conditions, school sense of coherence and subjective health complaints. A multilevel analysis of ninth-grade pupils in the Stockholm area. Journal of Adolescence, 34(1), 129-139.

Moksnes, U. K., Espnes, G. A., \& Haugan, G. (2013). Stress, sense of coherence, and emotional symptoms in adolescents. Psychology \& Health, 29(1), 32-49.

Moksnes, U. K., Espnes, G. A., \& Haugan, G. (2014). Stress, sense of coherence and emotional symptoms in adolescents. Psychology \& Health, 29(1), 32-49.

Moksnes, U. K., Espnes, G. A., \& Lillefjell, M. (2012). Sense of coherence and emotional health in adolescents. Journal of Adolescence, $35(2), 433-441$.

Moksnes, U. K., \& Haugan, G. (2015). Stressor experience negatively affects life satisfaction in adolescents: The positive role of sense of coherence. Quality of Life Research, 24(10), 2473-2481.

Moksnes, U. K., \& Lazarewicz, M. (2016). The association between self-esteem and sense of coherence in adolescents aged 13-18 years-The role of sex and age differences. Personality and Individual Differences, 90, 150-154.

Moksnes, U. K., Rannestad, T., Byrne, D. G., \& Espnes, G. A. (2011). The association between stress, sense of coherence and subjective health complaints in adolescents: Sense of coherence as a potential moderator. Stress and Health, 27(3), e157-e165.

Myrin, B., \& Lagerström, M. (2006). Sense of coherence and psychosocial factors among adolescents. Acta Paediatrica, 97(6), 805-811.

Neuner, B., Busch, M. A., Singer, S., Moons, P., Wellmann, J., Bauer, U., \& Hense, H. W. (2011). Sense of coherence as a predictor of quality of life in adolescents with congenital heart defects: A register-based 1-year follow-up study. Journal of Developmental and Behavioral Pediatrics, 32(4), 316-327.

Nielsen, A. M., \& Hansson, K. (2007). Associations between adolescents' health, stress and sense of coherence. Stress and Health 23(5), 331-341.

Nilsson, B., Holmgren, L., Stegmayr, B., \& Westman, G. (2003). Sense of coherence-stability over time and relation to health, disease, and psycho-social changes in a general population: A longitudinal study. Scandinavian Journal of Public Health, 31(4), 297-304.

Nio, K. (2010). Sense of coherence in adolescents with congenital cardiac disease. Cardiology in the Young, 20(5), 538.

Peled, D., Sagy, S., \& Braun-Lewensohn, O. (2013). Community perception as coping resource among adolescents living under rocket fire: A salutogenic approach. Journal of Community Positive Practices, 4, 681-702. 
Ristkari, T., Sourander, A., Rønning, J. A., et al. (2009). Childhood psychopathology and sense of coherence at age 18: Findings from the Finnish from a boy to a man study. Social Psychiatry and Psychiatric Epidemiology, 44(12), 1097-1105.

Rivera, F., García-Moya, I., Moreno, C., \& Ramos, P. (2013). Developmental contexts and sense of coherence in adolescence: A systematic review. Journal of Health Psychology, 18(6), 800-812. https://doi.org/10.1177/1359105312455077

Rizou, I., De Gucht, V., Papavasiliou, A., \& Maes, S. (2017). Evaluation of a self-regulation based psycho-educational pilot intervention targeting children and adolescents with epilepsy in Greece. Seizure, 50, 137-143.

Romeo, R. D. (2013). The teenage brain: The stress response and the adolescent brain. Current Directions in Psychological Science, 22, $140-145$.

Sagy, S., \& Braun-Lewensohn, O. (2009). Adolescents under rocket fire: When are coping resources significant in reducing emotional distress? Global Health Promotion, 16(4), 5-15.

Sagy, S., \& Dotan, N. (2001). Coping resources of maltreated children in the family: A salutogenic approach. Child Abuse \& Neglect, 25(11), 1463-1480.

Schreuder, E., Rijnders, M., Vaandrager, L., Hassink, J., Enders-Slegers, M. J., \& Kennedy, L. (2014). Exploring salutogenic mechanisms of an outdoor experiential learning programme on youth care farms in the Netherlands: Untapped potential? International Journal of Adolescence and Youth, 19(2), 139-152.

Simonsson, B., Nilsson, K. W., Leppert, J., \& Diwan, V. K. (2008). Psychosomatic complaints and sense of coherence among adolescents in a county in Sweden: A cross-sectional school survey. BioPsychoSocial Medicine, 2(4), 8.

Smith, L. O., Elder, J. H., Storch, E. A., \& Rowe, M. A. (2015). Predictors of sense of coherence in typically developing adolescent siblings of individuals with autism spectrum disorder. Journal of Intellectual Disability Research, 59(1), 26-38.

Somerville, L. H., Hare, T., \& Casey, B. J. (2011). Frontostriatal maturation predicts cognitive control failure to appetitive cues in adolescents. Journal of Cognitive Neuroscience, 23(9), 2123-2134.
Spear, L. (2013). The teenage brain: Adolescents and alcohol. Current Directions in Psychological Science, 22, 152-157.

Super, S., Verkooijen, K., \& Koelen, M. (2018). The role of community sports coaches in creating optimal social conditions for life skill development and transferability-a salutogenic perspective. Sport, Education and Society, 23(2), 173-185.

Tottenham, N., Hare, T. A., \& Casey, B. J. (2011). Behavioral assessment of emotion discrimination, emotion regulation, and cognitive control in childhood, adolescence, and adulthood. Frontiers in Psychology, 2, 39. https://doi.org/10.3389/fpsyg.2011.00039

Ustinavičienė, R., Škèmienè, L., Lukšienė, D., Radišauskas, R., Kalinienė, G., \& Vasilavičius, P. (2018). Association between computer game type, playing time and sense of coherence in Lithuanian adolescents. Central European Journal of Public Health, 26(3), 209-214.

Vilija, M., \& Romualdas, M. (2014). Unhealthy food in relation to posttraumatic stress symptoms among adolescents. Appetite, 74, 86-91.

Wadsby, M., Priebe, G., \& Svedin, C. G. (2014). Adolescents with alternating residence after parental divorce: A comparison with adolescents living with both parents or with a single parent. Journal of Child Custody, 11(3), 202-215.

Wang, Q., Hay, M., Clarke, D., \& Menahem, S. (2014). Associations between knowledge of disease, depression and anxiety, social support, sense of coherence and optimism with health-related quality of life in an ambulatory sample of adolescents with heart disease. Cardiology in the Young, 24(1), 126-133.

Würtz, E. T., Fonager, K., \& Mortensen, J. T. (2015). Association between sense of coherence in adolescence and social benefits later in life: A 12-year follow-up study. BMJ Open, 5(1), e006489.

Xu, F., Cui, W., Xing, T., \& Parkinson, M. (2019). Family socioeconomic status and adolescent depressive symptoms in a Chinese low- and middle-income sample: The indirect effects of maternal care and adolescent sense of coherence. Frontiers in Psychology, 10, 819.

Open Access This chapter is licensed under the terms of the Creative Commons Attribution 4.0 International License (http://creativecommons. org/licenses/by/4.0/), which permits use, sharing, adaptation, distribution and reproduction in any medium or format, as long as you give appropriate credit to the original author(s) and the source, provide a link to the Creative Commons license and indicate if changes were made.

The images or other third party material in this chapter are included in the chapter's Creative Commons license, unless indicated otherwise in a credit line to the material. If material is not included in the chapter's Creative Commons license and your intended use is not permitted by statutory regulation or exceeds the permitted use, you will need to obtain permission directly from the copyright holder. 